Tadesse, T., \& Melaku, T. (2019). Analysis of the relative impact of monetary and fiscal policies on economic growth in Ethiopia, using ARDL approach to co-integration: which policy is more potent? Copernican Journal of Finance \& Accounting, 8(2), 87-115. http://dx.doi.org/10.12775/ CJFA.2019.010

\author{
TeKILU TADESSE* \\ Jimma University
}

Tesfaye Melaku**

Jimma University

\title{
ANALYSIS OF THE RELATIVE IMPACT OF MONETARY \\ AND FISCAL POLICIES ON ECONOMIC GROWTH IN ETHIOPIA, USING ARDL APPROACH TO CO-INTEGRATION: WHICH POLICY IS MORE POTENT?
}

Keywords: monetary policy, fiscal policy, ARDL, economic growth, Ethiopia.

J E L Classification: E01, E52, E62.

Abstract: Empirical investigation on the comparative potency of monetary and fiscal policies is still dubious among two major schools of thought in economics so called classical and Keynesian. Hence, this paper investigates the relative effectiveness of monetary and fiscal policies in affecting economic growth by employing Auto-Regressive Distributive Lag Model (ARDL) for the time spanning from 1975 to 2017. The proxies used in this study for monetary and fiscal policy were Broad money supply (M2) and govern-

Date of submission: July 7, 2019; date of acceptance: August 8, 2019.

* Contact information: tekitade.tt@gmail.com, Department of Economics, Jimma University, Ethiopia, phone: +251983204432; ORCID ID: https://orcid.org/0000-00016029-9022.

** Contact information: tesamelua@gmail.com, Department of Economics, Jimma University, Ethiopia, phone: +251910209644; ORCID ID: https://orcid.org/0000-00023686-974X. 
ment consumption expenditure respectively while real GDP at constant prices in 2010 is used as proxy for economic growth in Ethiopia. Anderson and Jordan (1968) "St. Louis equation" has been used to estimate the comparative potency of monetary and fiscal policies. The empirical results indicate that both the monetary and fiscal policies have equal statistically significant and positive impact on economic growth in Ethiopia with different significance level and magnitude. Besides of equal effectiveness, the elasticity of real output with respect to fiscal policy variable is greater than the elasticity with respect to money supply which show fiscal policy is more effective than monetary policy in influencing Real GDP in the long-run. However, in the short run, the fiscal policy is effective while that of the monetary policy proxy by money supply is ineffective in affecting output growth in Ethiopia. Therefore, to have continuous and sustainable economic growth, the coordination of monetary and fiscal policies are vital and the lack of this coordination leads to a sharp downturn of overall economic performance, even can hurt the economy.

\section{INTRODUCTION}

\section{Background of the study}

Unquestionably, macroeconomic policies act a vital part in promoting and achieving maintainable and adequate economic environment which creates it conceivable for an economy to achieve a more rapidly, steady and persistent growth without aggravating inflation. This essential role is undertaken by the two leading tools of macroeconomic policy so called Monetary and fiscal policies in an economy. Responding to the economic fluctuation is regarded as the main aim of using monetary and fiscal policy tools by policymaker. Even though well-known formulation of monetary policy is towards controlling inflation and fiscal policy designed to the issue of public finance, both policies can be employed to respond to economic activity (Șen \& Kaya, 2015).

However, the relative effectiveness of both monetary and fiscal policies has been left to argument between two schools of thought namely the Keynesians and Monetarists since 1960s. In this point of view, there is still on-going debate and argument among different scholars from both theoretical and empirical perspectives. According to Keynesians argument, conducting fiscal policy as compared to monetary policy is strong and more effective in boosting economic activity through increasing aggregate demand, whereas the Monetarists in contrast claiming that monetary policy is more powerful effect on macroeconomic variables. According to monetarists, monetary urge is the most imperative factor contributing for fluctuation in output, employment and prices. As 
argued by Milton Friedman (1974) money stock is all that matters for variation in nominal income and for the short run deviations in real income as an overstatement and forwarded that pure fiscal policies namely increasing government expenditure or reduction in tax cannot effect real output.

Their justifiable empirical and theoretical based disagreement between two main extreme schools of thought has never come up with clear-cut conclusion and has been continued unending investigation among academic, economists and policymakers. The early seminal paper by Andersen and Jordon (1968) developed empirical policies debate on issue that which police is more powerful and effective in effecting output growth. In throughout literature review, still there is no credible evidence-based empiric has been found in relation to the relative effectiveness of monetary and fiscal policies on economic activity (Özer \& Karagöl, 2018).

Moreover, more recent global recession occurrence since 2008 financial crisis have acknowledged a renewed debate about the relative effectiveness of monetary and fiscal policies on economic activity though there had been widely believed statement among different scholars that implementing fiscal policy is more complex process and controversy than applying monetary policy instrument which is easily managed and controlled by certain authorized body in behalf of government (Sen \& Kaya, 2015). In contrast to aforementioned argument, as is mentioned by (Guerguil, Mandon \& Tapsoba, 2017) and (Özer \& Karagöl, 2018), due to large and prolonged growth and employment costs of the crisis, monetary policy has limited effect when interest rates are wedged at the zero lower-bound, and the essential of increased public expenditure to tackle a "secular stagnation" in this economic phenomena, there is a tendency of agreement among economists and policy makers for the powerfulness of fiscal policy as a countercyclical macroeconomic policy tool.

The aim of this paper is to examine the relative effectiveness of monetary and fiscal policies on output growth in Ethiopia over the period of 1980 and 2016/17 by using ARDL Bounds test approach to co-integration "via the St. Louis approach". To the best of our knowledge, this study the first attempted to provide empirical evidence on comparative efficiency of monetary and fiscal policies on output growth in case of Ethiopia which is long-lasting debate among academics and policy makers. Moreover, the data used in this research are more updated and cover wider span of time providing more degrees of freedom and power that enables to obtain more efficient parameter estimates from model. 


\section{THE RESEARCH METHODOLOGY AND THE COURSE OF THE RESEARCH PROCESS}

The article presents the following research problems:

- Does the monetary policy is relatively more effective than fiscal policy in changing real output of Ethiopia?

- Is there exists a strong relation between fiscal and monetary policy variables and economic growth in Ethiopia?

- How can macroeconomic stability be achieved in Ethiopia?

The general objective of this study is to examine the relative effectiveness of monetary and fiscal policies in affecting economic growth in Ethiopia using annual data from 1980 to 2017.

Specific objective:

- To examine the short-run and long-run impact of Monetary and fiscal policies on economic growth in Ethiopia;

- To investigate the relative effectiveness of monetary over fiscal policy on economic growth of the country.

This study explores examine the relative effect of monetary and fiscal policies in affecting economic growth in Ethiopia. To achieve this objective, time series data ranging from 1981/82 to 2016/17 are chosen. The whole period is chosen due to the availability of published data for all the variables involved in the model and to avoid using multiple data sources for the same variable.

We believe that study is important because it attempts to fill the gap in the literature in which study can be taken as reference for those who will undertake a study on the area of relative effect of monetary and fiscal policies on economic growth. Moreover, the result of this study is expected to provide relevant information for policy makers in formulation of macroeconomic policies issue and their intervention to achieve macroeconomic objectives for instance economic growth.

\section{MONETARY AND FISCAL POLICIES IN ETHIOPIA}

The ultimate macroeconomic policy goal of any country in general is to have sustainable economic growth and development. Policy measures are geared at achieving moderate inflation rate, keeping unemployment rate low, balancing foreign trade, stabilizing exchange and interest rates, etc and in general attaining stable and well-functioning macro-economic environment. In this 
process, monetary policy plays a central role. For instance, during economic recession where output falls with a fall in aggregate demand, monetary policy aims at increasing demand and hence production as well as employment will follow the same pattern of demand. In contrast, at the time of economic boom where demand exceeds production and treat to create inflation, the monetary policy instruments are utilized that could offset the condition and achieve price stability by counter cyclical action upon money supply (Johnston \& Sundararajan, 1999).

Monetary Policy is commonly understood as, "the deliberate application of monetary variables by the government (Central banks in most cases) to influence the general economic environment" (Ayubu, 2013) whereas fiscal policy is one of major macroeconomic policies in which a Government uses its spending and taxation powers to monitor and influence a nation's economy. Despite the difference in the way they are applied, monetary policies and fiscal are mainly targeted to reduce unemployment, enhance price and exchange rate stability, and attain maximum output. Currently, the National Bank of Ethiopia (NBE) is the banker of the government responsible to set and regulate the overall monetary policy actions on behalf of the government (Minyahil, Wndaferahu \& Yilkal, 2016).

Ethiopian economy had passed through different regimes and, hence economic policies had formulated differently. As a result, national economic policies were set in line with the respective regime's political ideology as policies are directed with the intention of achieving a wide range of macroeconomic objectives. According to Alemayehu (2001), under the regime of command economy in Ethiopia, the financial sector was governed by the then socialistic ideology; and as a result, interest rates were set at levels to discourage private ownership in the sector in particular and the economy in general. So as to control money supply, limited Credits were channeled only at the will of the central government to the selected target sectors. As result, the lowest growth of real GDP was experienced along with the severe drought the country encountered during this regime. The Derg regime is to blame, however, as its any macroeconomic policies couldn't ensure creditable rate of growth even during periods of conducive environment and failed to transform the structure of the economy with formulative policies. This was basically emanated from different factors including improper monetary policy, fiscal profligacy, inadequate financial regulation, and exchange rate policies under command economy. Unfortunately, whatever the underlying causes have been in this period, the economy's vola- 
tile structure has been a major obstacle and problem for sustainable economic growth in Ethiopia.

After the fall of Derg regime 1991, new government adopted free market approach following structural adjustment program directed by world bank to developing countries in which Ethiopia is one, monetary policy instruments were shifted to the market mechanism from direct government control. As result, economic reforms geared towards a free-market system and regional economic integration. Government monopoly on key production and financial sectors has been eased by allowing private-sector operators and a semi-market-determined exchange rate system was adopted rehabilitate the structure of economy. Even though not significant until 2000s, the shift of policy to one encouraging the participation of the private sector could have also partly helped the economy to revive in which financial regulation reform system particularly private participation on financial sector contributed a lot.

From 2003 onwards, Ethiopia came across with remarkable change in overall economic activities due to government attention towards the investment in infrastructure more than any other time (regime) ever in the history of the country. Indeed, the leader has guaranteed that his government is determined to set Ethiopia off serving the poster child of poverty. The substantial government expenditure on infrastructure could have been possibly crowding in private investment. However, following commodity price surges in 2007-2008 one of critical problem that Ethiopia encountered was rising inflation and falling international reserves. For instance, Overall consumer price inflation peaked at 64 percent in 2008 and international reserves fell to 1 month of imports at endOctober 2008. In response to this shock, central government in coordination with National Bank of Ethiopia adopted a policy package that include substantial fiscal and monetary adjustments, notably the elimination of fuel subsidies, as well as measures to protect vulnerable groups was front line measurement. Government expenditure financing policy was well managed to support the monetary policy measures taken at the time. This contributed to lowering the inflation, in addition to administrative measures taken to arrest the inflationary situation. Government has curtailed the domestic financing to the possible minimum, continued its effort in allocating more resources to productive (capital) expenditure, purchase and distribute imported basic food items (wheat, edible oil and sugar) at low prices to poor urban households from the budgetary sources. Such measures brought positive results and inflation has been stabilized and remained in a single digit in subsequent years (MOFEC, 2018). 
Moreover, fiscal policy continued to focus on increasing tax revenue by strengthening tax administration and enforcement, while covering a greater proportion of government expenditures from domestic resources. These government expenditures have largely been geared towards enhancing capital expenditure and pro-poor social spending programs and promoting safety nets. Thus, domestic revenue recorded a 5.1 percent annual growth while general government expenditure showed a 7.6 percent increment resulting in a budget deficit equivalent to 3 percent of GDP, higher than 2.8 percent of GDP target set in the GTP II plan (NBE, 2018).

Over all, the robust and sustained economic growth recorded over the last 15 years has led to improvements in income inequality and poverty reduction. Accordingly, per capita income has continuously increased and reached USD 883 in 2017/18. Poverty has declined to 22 percent from 38.7 percent in 2004/05. Investment to GDP ratio has increased to 34.1 percent while that of domestic savings rose to 22.4 percent. Despite the recent uptick, inflation has been kept within single digit level in 2017/18 largely aided by tight monetary and prudent fiscal policy stance. Yet, the annual average headline inflation rose to 13.1 percent in 2017/18 from 7.2 percent a year earlier due to the rise in both food and non-food inflation. Similarly, annual headline inflation went up to 14.7 percent from 8.8 percent owing to 6.7 percentage point and 4.9 percentage point increase in food inflation and non-food inflation respectively (Ibid).

\section{EMPERICAL LITERATURE REVIEW}

In this section we focus on the empirical studies because recent literature comprises a lot of studies which have outlined the effects of monetary and fiscal policies on output growth and its investigation has been ongoing as well. Particularly, in last two or three decades, a plenty of studies analyzing the relative effect of fiscal policy and monetary policy on real macroeconomic variables has widely increased throughout the world. This may be contributed towards increasing position of fiscal policy in fighting economic problem and stagnation which were manifested in a number of both developed and developing countries.

As pointed out in (Özer \& Karagöl, 2018), The relationship between fiscal and monetary policies and growth has conducted a lot of number of empirical investigation come up with mixed conclusion across different cross sectional, time series and panel data, such as, OLS, Panel data models, VAR model, VEC 
Model and ARDL Model. The majority of the finding confirmed that fiscal and monetary policies are certainly affect growth. In the studies, the outcome the variation of outcome largely accounted by the estimation techniques employed and/or the types of variable used in model.

Study conducted by Andersen and Jordan (1968) takes different measures of monetary and fiscal policy measures effectiveness in the United States using quarterly data, and implied that monetary policy proxied by money supply has greater, faster and more predictable impact on economic performance than fiscal policy instruments proxied by government expenditure. They concluded that forwarded that to stabilize the economy it is better to use monetary policy.

Early study by Owoye and Olugbenga (1994) analyzed the comparative effect of monetary and fiscal policies on output growth in sample of ten African countries namely Burundi, Ethiopia, Ghana, Kenya, Morocco, Nigeria, Sierra Leone, South Africa, Tanzania and Zambia-by using a Trivariate Vector Autoregressive (VAR) model over the year from 1960 to 1990. They found that effect of monetary policy stronger than fiscal variables in 5 of 10 countries whereas fiscal policy is more significant than monetary policy for the rest five countries. Regarding to their finding, the argument was that it is not allowed to provide conclusion of a particular macroeconomic policy stimulate economic growth. Another later cross-country study by Petrevski, Bogoev and Tevdovski (2015) investigated the relative importance of monetary and fiscal policies in increasing output in three South Eastern Europe economies: Bulgaria, Croatia, and Macedonia by using the recursive VARs to the quarterly data for 1999-2011, their result confirmed that positive fiscal shocks encourage higher output growth in the all countries, inferred to the expansionary effects of fiscal consolidation.

Moreover, more recent period different study conducted in different countries study; one confirms fiscal policy tool others support monetary policy, for instance, study by Jawaid, Arif and Naeemullah (2010) analyzed the relative outcome of the two powerful macroeconomic policy instrument on economic performance in Pakistan during the period 1981-2009 come up with the existence a positive relationship between both policies and growth in long-run. Conversely, their finding revealed that monetary policy is more potent effect than fiscal policy in accelerating growth.

An additional topical country-specific study by Havi and Enu (2014) analyzed the relative importance of monetary and fiscal policy on growth in Ghana by using estimation of OLS techniques for the period1980-2012. Their study 
showed that although the effect of monetary policy is more powerful, both policies positively affect growth in the case of Ghana. Similar result was obtained by Șen and Kaya (2015) who confirmed that both monetary and fiscal policies are positive and significant effects on output performance in Turkey. However, regarding to relative effectiveness, they found that the monetary policies has larger outcome in stimulating economic growth than monetary policies. Based on the finding they suggested that both policies significantly affect growth in which they should be implemented mutually in an efficient way to accelerate growth.

In more recently, Bokreta and Benanaya (2016) investigated the relative effectiveness of monetary and fiscal policy in case of Algeria employing co-integration and vector error correction model, and found that there is strong positive statistically significant impact of government expenditures on output growth, whereas the effect of taxes is found to be negative sign in long run, inferring that fiscal policy has strong effect than monetary policy in promoting economic growth in Algeria. The same conclusion has drawn by Okorie, Sylvester and Simon-Peter, (2017) used the auto regressive distributed lag (ARDL) model to determine the relative importance of monetary and fiscal policies in Nigeria using a quarterly time-series from 1981-2012. They confirmed that those both monetary and fiscal policies have significant positive impact national income. However, comparatively, this monetary policy outcome is stronger than income faster than fiscal policy in promoting economic growth in short run but, in the long-run fiscal policy dominates its effect that is total impact of fiscal policy is greater than that of monetary policy and concluded that they supports the use of both policies to achieve macroeconomic objectives primarily economic performance depends on the objective the authorities want to achieve.

Similarly, the study conducted by Özer and Karagöl (2018) who analyzed the relative growth effectiveness of fiscal and monetary policies in Turkey over the period 1998 and 2016 by using the techniques of ARDL Bounds testing, structural Granger causality tests and their result indicates that Monetary policy variable is creating only short-run effects on growth; but, does not cause any Granger causality on it, that is fiscal policy variable has a long-run significant effect and causing to growth. As result they concluded that the fiscal policy seems to be more effective than monetary policy during examination period, implying the rethinking the implementation of both policies to achieve past economic growth. 
Overall, in reviewing the related literature we can conclude that although there are the enormous studies examining the relative effectiveness of monetary and fiscal policies, the empirical findings of these studies are highly mixed. In other words, the empirical studies reveal inconclusive results with regard to the relative effectiveness of two potent macroeconomic policy tools. For instance, in some countries monetary policy is dominant to fiscal policy or vice versa, while in others the results is inconclusive. These results do not allow us to make a generalization with regard to the relative effectiveness of monetary and fiscal policies. The contradictory empirical results which emerged from the studies above may be attributed to a number of factors, depending on country-specific elements such as institutional, developmental, political and so on as well as methodological approaches, variables chosen, treatment, etc. (Sen \& Kaya, 2015).

\section{DATA AND MODEL SPECIFICATION}

\section{Data type and source}

Regarding data type, the study used secondary time series data for about 35 years obtained from internal and external sources. The selection of this sample size is made based on the availability of data for each of the variable included in the model for the entire time horizon while its sufficiency is taken into consideration as well. The major sources of data for the problem under investigation were Ministry of Finance and Economic Cooperation (MoFEC), publications of National Bank of Ethiopia (NBE), Central Statistics Authority (CSA) of Ethiopia, Ministry of Education and Ethiopian Revenue and customs authority (ERCA). In addition to these domestic sources, some variables for which there are no sufficient data from the domestic sources, are collected from external sources, especially from IMF and WB databases.

\section{Data and methodology}

To analyze the relative effectiveness of monetary and fiscal policies on economic growth, we employed the equation proposed by Andersen and Jordan (1968) which is so called St. Louis equation. The justification behind the use of this equation is that St. Louis has received much consideration from the policy 
maker's researchers and academicians regardless of its drawback in relation to methodology and variables. Its mathematical expression can be represented as:

$$
Y=f(M F W)
$$

Where: Y stand for the economic growth measures for well being of society; F represents fiscal policy variables; $\mathrm{M}$ monetary policy variables, and $\mathrm{W}$ represents other control variables influencing economic performance.

The from above equation, the explanatory variables used in the model comprises of government total final consumption as \% of GDP proxy for fiscal policy, broad money supply as \% of GDP proxy for monetary policy and other control variables are real interest rate, CPI inflation, nominal exchange rate and trade openness to address the problem of omitted variable biasedness from "St. Louis equation" where as economic growth measured by real GDP. The equation could be rewritten in form of log-linear form to be employed in this study here as follows:

$$
\begin{aligned}
& \ln R G D P=\beta_{0}+\beta_{1} \ln M_{2}+\beta_{2} \ln G E+\beta_{3} \ln I N R+\beta_{4} \ln C P I+ \\
& +\beta_{5} \ln N E R+\beta_{6} \ln T O+U_{i}
\end{aligned}
$$

Where:

RGDP $=$ Real gross domestic product used to measure economic performance

M2 = Broad money supply as \% of GDP (proxy for monetary policy)

$\mathrm{GE}=$ Government final consumption AS \% of GDP (proxy for fiscal policy)

INR $=$ Real interest rate

$\mathrm{CPI}=$ Consumer price index used to measure inflation

NER = real effective exchange rate

T0 = Trade openness (export plus import as \% of GDP) measures liberalization of trade. 


\section{ESTIMATION PROCEDURES}

\subsection{Unit Root Test}

The necessary condition to be addressed for testing unit root test is to check whether the variables enter in the regression are not order two (I.e. I(2)) which is a precondition in employing ARDL model. Therefore, running any sort of regression analysis is impossible without testing for time series variables. So, the first step in this study is testing unit root before running regression analysis.

The testing procedure for the ADF unit root test is specified as follows:

$$
X_{t}=\alpha+\delta t+\mu X_{t-1}+\sum_{i=1}^{\rho} \lambda \Delta X_{t-i}+\varepsilon_{t}
$$

Where $\boldsymbol{X}_{\boldsymbol{t}}$ is a time series variables which are mentioned above in this model at time $t, t$ is a time trend variable; $\Delta$ denotes the first difference operator; $\rho$ is the error term; is the optimal lag length of each variable chosen such that first-differenced terms make $\varepsilon_{t}$ a white noise. Thus, the ADF test the null hypothesis of no unit root (stationary) which is expressed as follows:

$$
H_{0}: \mu=0 ; H_{1}: \mu \neq 0
$$

Regarding decision of unit root test, if the t value or t-statistic is more negative than the critical values, the null hypothesis (I.e. HO) is rejected and the conclusion is that the series is stationary. Conversely, if the t-statistic is less negative than the critical values, the null hypothesis is accepted and the conclusion is that the series is non-stationary. Failure to reject the null hypothesis of unit root test leads to take the test on the difference of the time series to come up out with stationary variable for analysis.

\subsection{Autoregressive Distributed Lag (ARDL) Bounds testing approach}

To determine the existence of long-run equilibrium relationships between variables, which is co-integration, we use the Autoregressive Distributed Lag 
(ARDL) Bounds testing approach developed by Pesaran and Shin (1998) and later expanded by Pesaran, Shin and Smith (2001). One of the most important advantages of the ARDL method is that the variables used in the analysis can have mix of different degrees of integration; that is, they can be a mix of I (0) or I (1). Also, with the help of using this approach, one is allowed to estimate short-run, long-run effects simultaneously by forming an Error Correction Model (ECM) derived from the ARDL model without loss of long-term information. Moreover, it provides efficient and unbiased estimator in small sample size and it has an opportunities to determine different lag length with their respective variables. So, an unrestricted error correction representation of the ARDL framework of Equation (2) can be written as:

$$
\begin{aligned}
\Delta \ln R G D P_{t}= & \beta_{0}+\beta_{1} \operatorname{lnRGDP}_{t-1}+\beta_{2} \ln _{2} M_{t-1}+\beta_{3} \ln G E_{t-1}+\beta_{4} \operatorname{lnINR}_{t-1}+\beta_{5} C P I_{t-1} \\
& +\beta_{6} \ln N E R_{t-1}+\beta_{7} \ln T O_{t-1}+\sum_{i=1}^{q} \alpha_{i} \Delta \ln R G D P_{t-1}+\sum_{j=1}^{c} \alpha_{j} \Delta \ln M_{2 t-j} \\
& +\sum_{k=1}^{r} \alpha_{k} \Delta \ln G E_{t-k}+\sum_{l=1}^{s} \alpha_{l} \Delta \operatorname{lnINR_{it-l}}+\sum_{m=1}^{v} \alpha_{m} \Delta \operatorname{lnCPI} I_{t-m} \\
& +\sum_{n=1}^{y} \alpha_{n} \Delta L N N E R_{t-n}+\sum_{o=1}^{w} \alpha_{0} \Delta \operatorname{lnTO} O_{t-o}+U_{t}
\end{aligned}
$$

So as to test for presence of a long-run relationship among the variables of interest, meaning to test the co-integration existence, between economic performance and all explanatory variables, first estimation Equation (2) by ordinary least squares (OLS) was estimated and then undertake an F-test for overall significance of the coefficients of the lagged levels of the variable. Thus, to test the null hypothesis of no cointegration relationship among the variables from equation (2) defined as:

$$
H_{O}=\beta_{1}=\beta_{2}=\beta_{3}=\beta_{4}=\beta_{5}=\beta_{5}=\beta_{6}=\beta_{7}=0
$$

against the alternative hypothesis of the existence of co integrating relationship between the variables.

$$
H_{1} \neq \beta_{1} \neq \beta_{2} \neq \beta_{3} \neq \beta_{4} \neq \beta_{5} \neq \beta_{5} \neq \beta_{6} \neq \beta_{7} \neq 0
$$


To determine the result of the test, the Wald-test (F-statistic) was employed. As mentioned detail in Özer and Karagöl (2018), the asymptotic distribution of the F-test is non-standard under the null hypothesis of no co-integration among the variables, and rely on either variables incorporated in the ARDL model are I(0) or I(1), the number of explanatory variables, whether the ARDL model contains an intercept and/or a trend; and the sample size. Pesaran and Shin (1998) and Pesaran, Shin and Smith (2001). (2001) have come up with two critical values. The lower critical bound assumes all the variables are I (0), and the upper bound assumes that all the variables are I (1). When the computed value of F-statistic is greater than the upper bound critical value, we reject the $\mathrm{H}_{0}$ and accept alternative hypothesis of co-integration. In this case, our conclusion will be the existence of co-integration of variables. If the sample value F-statistic is less than the lower bound critical value, we refuse to reject the $\mathrm{H}_{0}$ and conclude that there is no co-integration among the variables. Finally, if the sample F-statistics value resulted between the lower and upper critical values, the outcome will be indecisive, and in this case one can test the statistical significance of speed of adjustment coefficient. Significant speed of adjustment coefficient in dictates the existence of co-integration among the variables.

ARDL approach was employed to estimate the short- and long-run dynamic relationships. Therefore, Equation (2) can be rewritten as the error correction version of ARDL model as follow:

$$
\begin{aligned}
& \Delta \ln R G D P_{t}=\beta_{0}+\sum_{i=1}^{p} \alpha_{i} \Delta \ln R G D P_{t-1}+\sum_{j=1}^{q} \alpha_{j} \Delta \ln M_{2 t-j}+\sum_{k=1}^{r} \alpha_{k} \Delta \ln G E_{t-k} \\
& +\sum_{l=1}^{s} \alpha_{l} \Delta \operatorname{lnIN} R_{i t-l}+\sum_{m=1}^{v} \alpha_{m} \Delta l n C P I_{t-m}+\sum_{n=1}^{y} \alpha_{n} \Delta L N N E R_{t-n} \\
& +\sum_{o=1}^{w} \alpha_{0} \Delta \ln T O_{t-o}+\gamma E C M_{t-1}+U_{t}
\end{aligned}
$$

Where: $E C M_{t-1}$ is the error correction model term which has to be negative and statistically significant and represents the speed of adjustment to long -run equilibrium following a short run shock. 


\section{Diagnostic tests}

For the diagnostic checking, we tested the presence of serial correlation and heteroscedasticity in the errors and normality of errors as well. Finally, by using CUSUM and CUSUMSQ tests, we were checked the stability of parameters of the model.

\section{Variable description and expected sign}

Table 1. Variable description and expected sign

\begin{tabular}{|l|l|l|c|}
\hline \hline Data & \multicolumn{1}{|c|}{ Description } & \multicolumn{1}{|c|}{ Unit of measurement } & Expected sign \\
\hline \hline RGDP & Real gross domestic product & Real gross domestic product in millions & + \\
\hline GEXP & Government consumption expenditure & $\%$, as a share of GDP & + \\
\hline$M_{2}$ & Broad money supply & $\%$, as a share of GDP & - \\
\hline INR & Nominal interest rate & $\%$ & $-/+$ \\
\hline CPI & Consumer price index & $\%(1998=100)$ & + \\
\hline NEER & Real effective exchange rate & $\%$ & $(\mathrm{X}+\mathrm{M}) \%$, as a share of GDP \\
\hline TO & Trade openness & + \\
\hline \hline
\end{tabular}

S o u r c e : author hypothesis.

\section{CAUSAlity ANALYSIS}

After confirming the long-run relationship between Real GDP and all explanatory variable by applying the ARDL bounds test and combined cointegration techniques, the Granger causality can be applied to investigate the direction of causality among the variables. The Error Correction Model (ECM) based Granger causality test is applied to investigate the direction of causality between the variables. 


$$
\begin{aligned}
\Delta \ln R G D P_{t}= & \beta_{0}+\sum_{i=1}^{p} \alpha_{i} \Delta \ln R G D P_{t-1}+\sum_{j=1}^{q} \alpha_{j} \Delta \ln M_{2 t-j}+\sum_{k=1}^{r} \alpha_{k} \Delta \ln G E_{t-k} \\
& +\sum_{l=1}^{s} \alpha_{l} \Delta \operatorname{lnIN} R_{i t-l}+\sum_{m=1}^{v} \alpha_{m} \Delta \ln C P I_{t-m}+\sum_{n=1}^{y} \alpha_{n} \Delta L N N E R_{t-n} \\
& +\sum_{o=1}^{w} \alpha_{0} \Delta \ln T O_{t-o}+\gamma E C M_{t-1}+U_{t}
\end{aligned}
$$

$$
\begin{aligned}
\Delta \ln M 2_{t}=\beta_{0} & +\sum_{i=1}^{p} \alpha_{i} \Delta \ln M 2_{t-1}+\sum_{j=1}^{q} \alpha_{j} \Delta \ln R G D P_{t-j}+\sum_{k=1}^{r} \alpha_{k} \Delta \ln G E_{t-k} \\
& +\sum_{l=1}^{s} \alpha_{l} \Delta \ln I N R_{i t-l}+\sum_{m=1}^{v} \alpha_{m} \Delta \ln C P I_{t-m}+\sum_{n=1}^{w} \alpha_{n} \Delta L N N E R_{t-n} \\
& +\sum_{o=1}^{w} \alpha_{0} \Delta \operatorname{lnT} O_{t-o}+\gamma E C M_{t-1}+U_{t}
\end{aligned}
$$$$
\Delta \ln G E P_{t}=\beta_{0}+\sum_{i=1}^{p} \alpha_{i} \Delta \ln G E P_{t-1}+\sum_{j=1}^{q} \alpha_{j} \Delta \ln M_{2 t-j}+\sum_{k=1}^{r} \alpha_{k} \Delta \ln R G D P_{t-k}
$$$$
+\sum_{l=1}^{s} \alpha_{l} \Delta \operatorname{lnIN} R_{i t-l}+\sum_{m=1}^{v} \alpha_{m} \Delta \operatorname{lnCPI} I_{t-m}+\sum_{n=1}^{y} \alpha_{n} \Delta L N N E R_{t-n}
$$$$
+\sum_{o=1}^{w} \alpha_{0} \Delta \ln T O_{t-o}+\gamma E C M_{t-1}+U_{t}
$$

$$
\begin{aligned}
\Delta \operatorname{lnIN} R_{t}=\beta_{0} & +\sum_{i=1}^{p} \alpha_{i} \Delta \operatorname{lnINR_{t-1}}+\sum_{j=1}^{q} \alpha_{j} \Delta \ln M_{2 t-j}+\sum_{k=1}^{r} \alpha_{k} \Delta \operatorname{lnGE} E_{t-k} \\
& +\sum_{\substack{l=1 \\
w}}^{s} \alpha_{l} \Delta \ln R G D P_{t-l}+\sum_{m=1}^{v} \alpha_{m} \Delta \ln C P I_{t-m}+\sum_{n=1}^{y} \alpha_{n} \Delta L N N E R_{t-n} \\
& +\sum_{o=1}^{w} \alpha_{0} \Delta \operatorname{lnTO} O_{t-o}+\gamma E C M_{t-1}+U_{t}
\end{aligned}
$$




$$
\begin{aligned}
& \Delta \ln C P I_{t}=\beta_{0}+\sum_{i=1}^{p} \alpha_{i} \Delta \ln C P I_{t-1}+\sum_{j=1}^{q} \alpha_{j} \Delta \ln M_{2 t-j}+\sum_{k=1}^{r} \alpha_{k} \Delta \ln G E_{t-k} \\
& +\sum_{\substack{l=1 \\
w}}^{s} \alpha_{l} \Delta \operatorname{lnINR_{it-l}}+\sum_{m=1}^{v} \alpha_{m} \Delta \ln R G D P_{t-m}+\sum_{n=1}^{y} \alpha_{n} \Delta L N N E R_{t-n} \\
& +\sum_{o=1}^{w} \alpha_{0} \Delta \ln T O_{t-o}+\gamma E C M_{t-1}+U_{t} \\
& \Delta \ln R E E R_{t}=\beta_{0}+\sum_{i=1}^{p} \alpha_{i} \Delta \ln R E E R_{t-1}+\sum_{j=1}^{q} \alpha_{j} \Delta \ln M_{2 t-j}+\sum_{k=1}^{r} \alpha_{k} \Delta \ln G E_{t-k} \\
& +\sum_{l=1}^{s} \alpha_{l} \Delta \operatorname{lnINR_{it-l}}+\sum_{m=1}^{v} \alpha_{m} \Delta \ln C P I_{t-m}+\sum_{n=1}^{y} \alpha_{n} \Delta R G D P_{t-n} \\
& +\sum_{o=1}^{w} \alpha_{0} \Delta \ln T O_{t-o}+\gamma E C M_{t-1}+U_{t} \\
& \Delta \operatorname{lnT} O_{t}=\beta_{0}+\sum_{i=1}^{p} \alpha_{i} \Delta \ln T O_{t-1}+\sum_{j=1}^{q} \alpha_{j} \Delta \ln M_{2 t-j}+\sum_{k=1}^{r} \alpha_{k} \Delta \ln G E_{t-k} \\
& +\sum_{l=1}^{s} \alpha_{l} \Delta l n I N R_{i t-l}+\sum_{m=1}^{v} \alpha_{m} \Delta l n C P I_{t-m}+\sum_{n=1}^{y} \alpha_{n} \Delta L N N E R_{t-n} \\
& +\sum_{o=1}^{w} \alpha_{0} \Delta \ln R G D P_{t-o}+\gamma E C M_{t-1}+U_{t}
\end{aligned}
$$

Where; ECTt-1presents the lagged error correction term and $\Delta$ represents the first difference to examine the short-run dynamic. Additionally, U1t, U2t represent the error terms and they should be white noise and serially uncorrelated. The ECM is an important model that distinguishes the short- and longrun Granger causalities. The lag of the individual coefficients is utilized to test the significance of the short-run relationship. Furthermore, the coefficient of ECTt-1is statistically significant and indicates long-run causality. Jointlylagged coefficients and the ECT are used to verify joint causality between the variables. 


\section{EMPIRICAL RESULTS}

Before carrying out a formal analysis, we need to check the initial requirements of time series annual data for the period of 1975 to 2017. Moreover, every time series data has trend and to find the pattern of trend we applied the unit root test. The results of Augmented Dickey Fuller (ADF) test are given below in table 2. Based on the Augmented Dickey Fuller (ADF) test, we do not reject null hypothesis and all variables are non-stationary at level. But in case of first difference we reject null hypothesis and all variables are integrated at order 1 , and order of integration is I (1).

Table 2. Augmented Dickey Fuller (ADF) Results

\begin{tabular}{|c|c|c|c|c|c|}
\hline \multirow[t]{2}{*}{ VARIABLE } & \multicolumn{2}{|c|}{ LEVEL } & \multicolumn{2}{|c|}{$1^{\text {ST }}$ DIFFERENCE } & \multirow{2}{*}{$\begin{array}{l}\text { ORDER OF } \\
\text { INTEGRATION }\end{array}$} \\
\hline & Intercept & $\begin{array}{l}\text { Intercept } \\
\text { and trend }\end{array}$ & Intercept & $\begin{array}{l}\text { Intercept } \\
\text { and trend }\end{array}$ & \\
\hline \multirow[t]{2}{*}{ LNRGDP } & 4.107452 & 1.727892 & -2.904909 & -3.633029 & \multirow[t]{2}{*}{$\mathrm{I}(1)$} \\
\hline & $(1.00000)$ & $(1.000000)$ & $(0.02837)^{* *}$ & $(0.0392)^{* *}$ & \\
\hline \multirow[t]{2}{*}{ LNM2 } & 1.949882 & -0.925755 & -3.890230 & -4.261654 & \multirow[t]{2}{*}{$\mathrm{I}(1)$} \\
\hline & (0.9998) & $(0.9433)$ & $(0.0049)$ & $(0.0090)^{*}$ & \\
\hline \multirow[t]{2}{*}{ LNGEXP } & -2.888047 & -2.625535 & -7.656396 & -7.761068 & \multirow[t]{2}{*}{$\mathrm{I}(1)$} \\
\hline & $(0.0554)^{* * *}$ & $(0.2717)$ & $(0.0000)^{*}$ & $(0.0000)^{*}$ & \\
\hline \multirow[t]{2}{*}{ LNREER } & -1.520558 & -1.941157 & -5.269592 & -5.205297 & \multirow[t]{2}{*}{$\mathrm{I}(1)$} \\
\hline & $(0.5136)$ & $(0.6154)$ & $(0.0001)^{*}$ & $(0.0007)^{*}$ & \\
\hline \multirow[t]{2}{*}{ LNCPI } & 0.443791 & 0.821348 & -5.071211 & -5.16035 & \multirow[t]{2}{*}{$\mathrm{I}(1)$} \\
\hline & $(0.9826)$ & $(0.9553)$ & $(0.0002)^{*}$ & $(0.0007)^{*}$ & \\
\hline \multirow[t]{2}{*}{ LNTO } & -1.038031 & -1.922031 & -5.905394 & -5.821702 & \multirow[t]{2}{*}{$\mathrm{I}(1)$} \\
\hline & $(0.7306)$ & $(0.6250)$ & $(0.0000)$ & $(0.0000)$ & \\
\hline \multirow[t]{2}{*}{ LNINTR } & -1.909132 & -2.485310 & -6.778059 & -6.692789 & \multirow[t]{2}{*}{$\mathrm{I}(1)$} \\
\hline & $(0.3251)$ & $(0.3334)$ & $(0.0000)^{*}$ & $(0.0000)^{*}$ & \\
\hline
\end{tabular}

S o u r c e : authors computation (2019). 


\section{BOUND TESTS FOR COINTEgRATION}

As the results of all variables are integrated at first order integration, to undertake appropriate bound test, we first determine the best ARDL model by using the Akaike Information Criterion (AIC). Pesaran and Shin (1998) and Narayan (2004) recommended us to use maximum 2 lags for annual data series of small sample observation. As the resulted indicated blow in table 2 reveals that we reject null hypothesis of no cointegration against alternative hypothesis, since the computed value of F-statistics (6.83238) is greater than the upper level of bounds critical value of 4.43 and lower bounds value of 63.15 for $\mathrm{k}=6$. This conclusion indicates that there is a long-term equilibrium relationship among variables. Having found a long run relationship by bound tests, we applied the ARDL method to examine the long run and short run parameters.

Table 3. Bound test for integration

\begin{tabular}{|c|c|c|}
\hline Levels & Bounds & Critical values \\
\hline $10 \%$ Level & $\begin{array}{ll}\text { Lower bound } & I(0) \\
\text { Upper bound } & I(1)\end{array}$ & $\begin{array}{l}2.12 \\
3.23\end{array}$ \\
\hline $5 \%$ Level & $\begin{array}{ll}\text { Lower bound } & I(0) \\
\text { Upper bound } & I(1)\end{array}$ & $\begin{array}{l}2.45 \\
3.61\end{array}$ \\
\hline $2.5 \%$ Level & $\begin{array}{ll}\text { Lower bound } & I(0) \\
\text { Upper bound } & I(1)\end{array}$ & $\begin{array}{l}2.75 \\
3.99\end{array}$ \\
\hline $1 \%$ Level & $\begin{array}{ll}\text { Lower bound } & I(0) \\
\text { Upper bound } & I(1)\end{array}$ & $\begin{array}{l}3.15 \\
4.43\end{array}$ \\
\hline F-Statistics ARDL(1,1,2,2,2,2,0) & & $6.832383^{*}$ \\
\hline
\end{tabular}

S o u r c e s: computed from EViews 9.5.

N o t e $:^{*}, * *$, and ${ }^{* * *}$ represents significance at the $1 \%, 5 \%$, and $10 \%$ levels, respectively. The Akaike Information Criterion (AIC) criterion is used to determine the optimal lag. The critical values are determined from Pesaran, Shin and Smith (2001).

\section{Diagnostic and Model Stability Tests}

The ECM model checked all short run diagnostic tests such as absence of serial correlation, no conditional autoregressive serial correlation, no heteroscedasticity and correctly specified functional form and distributed error term. The 
regression for the underlying ARDL equation fits very well at $\mathrm{R}^{2}=0.975$ and also one of the diagnostic tests checking which is presented in the following table.

Table 4. Short-run ECM version of ARDL $(1,1,2,2,2,2,0)$ Diagnostic Tests

\begin{tabular}{|l|c|c|c|c|}
\hline \multirow{2}{*}{\multicolumn{1}{|c|}{ TESTS }} & \multicolumn{2}{c|}{ LM-version } & \multicolumn{2}{c|}{ F-version } \\
\cline { 2 - 5 } & statistic & P-value & statistic & P-value \\
\hline \hline $\begin{array}{l}\text { A:Serial Correlation: Breusch-Godfrey } \\
\text { serial correlation LM test }\end{array}$ & $\chi 2(2)=10.554$ & 0.1331 & $F(2,29)=1.70249$ & 0.1910 \\
\hline $\begin{array}{l}\text { Heteroskedasticity: Breusch-Godfrey } \\
\text { test }\end{array}$ & $\chi 2(9)=4.181$ & 0.8991 & $F(9,31)=0.67357$ & 0.7262 \\
\hline Normality: Jarque-Bera test & $\chi 2(2)=0.32921$ & 0.84822 & Not applicable & \\
\hline Functional Form: Ramsey RESET test & $\chi 2(1)=.125801$ & 0.9010 & $F(1,22)=0.01582$ & 0.9010 \\
\hline \hline
\end{tabular}

S o u r c e : author's computation of Eview 9.5 result, 2019.

\section{The Stability Test}

The stability of the model is also verified with the help of the cumulative sum (CUSUM) and the cumulative sum of squares (CUSUMSQ) tests of stability. The CUSUM and CUSUM of squares tests for the stability were introduced by Brown, Durbin, Evans (1975) to check the stationarity of regression equations. The Brown et al. (1975) method used the straight lines as limits. If CUSUM crosses these linear limits at least once, then it is believed that the regression equation is unstable.

Accordingly, The cumulative sum (CUSUM) and cumulative sum of squares (CUSUMsq) plots from recursive estimation of the model also indicate stability of long run coefficients (figures 1 and 2) over the sample period because graphs of cumulative sum of squares (CUSUM) and (CUSUMsq) do not exceeds the critical boundaries of both the figures at $5 \%$ level of significance. 
Figure 1. Plot of Cumulative Sum of Recursive Residuals (i)

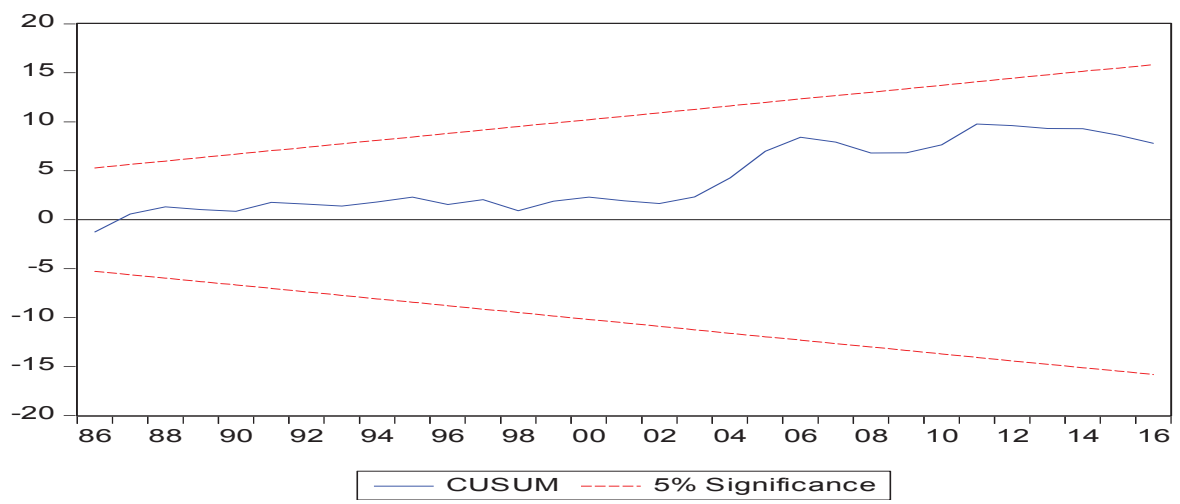

S o u r c e : author computation from Eview.

Figure 2. Plot of Cumulative Sum of Squares of Recursive Residuals (ii)

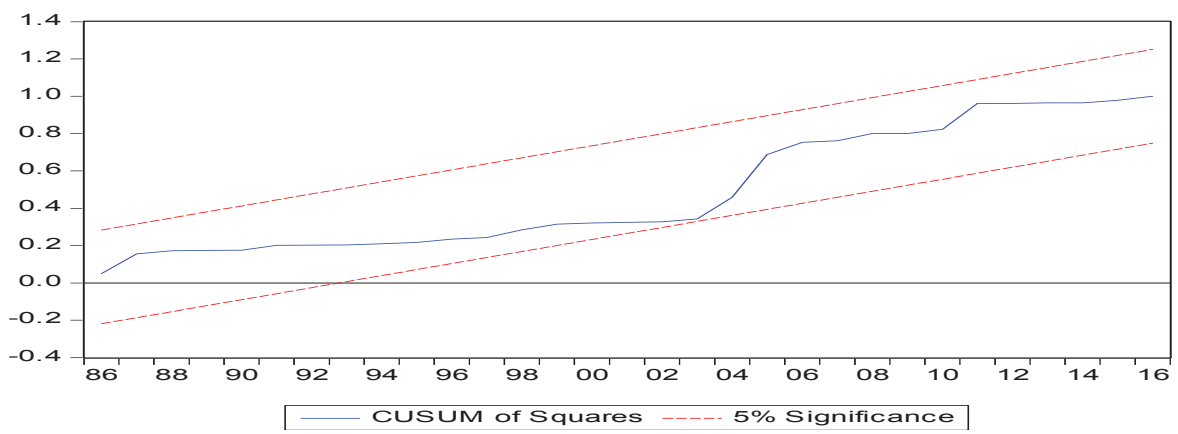

S o u r c e : author computation from Eview. 


\section{Estimated Long-Run CoEfFicients Using The ARDL APPROACH}

Table 5. Autoregressive Distributed Lag (ARDL) long-run results with the error correction term

\begin{tabular}{|l|c|c|c|c|}
\hline \hline \multicolumn{1}{|c|}{ Variable } & Coefficient & Std. Error & t-Statistic & Prob. \\
\hline \hline LNM2 & 0.180907 & 0.075890 & 2.383822 & $0.0258^{* *}$ \\
\hline LNGEXP & 0.439488 & 0.070273 & 6.254027 & $0.0000^{*}$ \\
\hline LNREER & -0.437287 & 0.169680 & -2.577125 & $0.0168^{* *}$ \\
\hline LNCPI & 0.446836 & 0.116918 & 3.821805 & $0.0009^{*}$ \\
\hline LNTO & 0.144639 & 0.057551 & 2.513251 & $0.0194^{* *}$ \\
\hline LNINTR & -0.385857 & 0.070647 & -5.461757 & $0.0000^{*}$ \\
\hline C & 6.331939 & 0.663379 & 9.544973 & $0.0000^{*}$ \\
\hline \hline
\end{tabular}

S o u r c e : computed from Eviews 9.5.

N o t e : the sign of "*” and "**” represents the level of significance at $1 \%$ and $5 \%$ respectively.

From the result we reveal that the money supply and government consumption expenditure have significant and positive impact on economic growth in long run. In other words, this study obtains strong and positive relation between money supply and the real GDP indicating that monetary policy is effective in affecting real GDP in Ethiopia. Similarly, the association between real GDP and government consumption expenditure proxy for fiscal policy is statistically significant and positive implying that fiscal policy is also effective in changing real GDP in Ethiopia. However, in terms of significant level and relative magnitude measured by elasticity of real GDP with respective of monetary and fiscal policy, it reveals that fiscal policy is comparatively more effective than monetary policy in the long run. The result is consistent with the findings of Ali, Irum and Ali (2008), Mohammad, Wasti, Lal and Hussain (2009), and Ozer and Kargol (2018) in Turkey.

Real effective exchange rate bears the negative and significant effects on the economic growth of Ethiopia in long run. It means an increase in real effective exchange rate which is the depreciation of Ethiopia currency against weighted trade partner's currencies deteriorates economic growth through adversely affecting the international competitiveness. This finding is contrasting with the traditional approach to exchange rate. Classical theory of the de- 
preciation has expansionary effects on economic growth through aggregate demand channel will not be applicable for Ethiopian economy rather other determinants are matter to enhance international competitiveness. Clearly speaking, the empirical results of this study imply that increase in real effective exchange rate so called depreciation hurts instead of promoting economic growth in the long run through increasing the cost of raw materials which are needed for further domestic production. This result against traditional view but, in line with modern macroeconomic view which states that depreciation of the domestic currency has a net effect of declining the economic growth. For the modern viewers, the effect of exchange rate on economic growth operate through the aggregate supply channel stating that developing countries such as Ethiopia experienced with heavy dependency on foreign capital for investment and the very low elasticity demand for their exporting primary commodities is low. Therefore, its negative impact through raising the costs of imported raw materials is overwhelming the positive effect it has on competitiveness through increasing exports. This result confirms the study of (Baylie, 2011) in Ethiopia and Razzaque, Bidisha and Khondker (2017) in Bangladesh.

The relationship between Real interest rate and economic growth is found to be negative and statistically significant at $1 \%$ level. The relationship between confirms economic theory of investment which state that for governments to encourage private investment, the real interest rate has to be reduced because increasing interest results crowding out effect of private investment spending thereby decreasing national income. From the result trade openness has found positive and significant impact on economic growth in Ethiopia which indicates that international trade competitiveness through trade liberalization plays a significant role in the economic growth of Ethiopia, confirming the trade-led growth hypothesis both in the long run. This finding consistent with Asfaw (2014), Zarra-Nezhad, Hosseinpour and Arman (2014), Brueckner and Lederman (2015) and Keho (2017); Ogundari and Awokuse (2018) and Evans and Kelikume (2018) but contradicts with Vlastou (2010), Polat, Shahbaz, Rehman and Satti (2015), Ulaşan (2015), Were (2015), Lawal, Nwanji, Asaleye and Ahmed (2016) who reported a negative or insignificant impact of trade openness on economic growth. This unexpected and contradicting previous result might be explained omitted important explanatory variables as suggested by Keho (2017). In contrast to the extensively accepted hypothesis that inflation creates a danger to economic activities, the results revealed that inflation has a positive and significant impact on the economic growth of Ethiopia. This 
outcome is similar with some empirical findings and the theoretical hypothesis of New-Keynesian school of economics stating that inflation per se is not something harmful for the economy of a nation in all situations.

\section{SHORT-RUN ECM VERSION OF ARDL MODEL}

Table 6. Short-run error correction model (Cointegrating Form)

\begin{tabular}{|l|c|c|c|c|}
\hline \hline \multicolumn{1}{|c|}{ Variable } & Coefficient & Std. Error & t-Statistic & Prob. \\
\hline \hline D(LNM2) & 0.037176 & 0.039500 & 0.941173 & 0.3564 \\
\hline D(LNGEXP) & 0.095571 & 0.031952 & -2.991113 & $0.0065^{*}$ \\
\hline D(LNGEXP(-1)) & 0.059062 & 0.028779 & 2.052282 & $0.0517^{* *}$ \\
\hline D(LNREER) & 0.070825 & 0.064106 & 1.104801 & 0.2807 \\
\hline D(LNREER(-1)) & 0.153937 & 0.078435 & 1.962594 & 0.0619 \\
\hline D(LNCPI) & -0.298235 & 0.092050 & -3.239915 & $0.0036^{*}$ \\
\hline D(LNCPI(-1)) & -0.337009 & 0.119670 & -2.816144 & $0.0098^{*}$ \\
\hline D(LNTO) & 0.068490 & 0.026675 & 2.567553 & 0.0172 \\
\hline D(LNINTR) & 0.016047 & 0.034149 & 0.469907 & 0.6428 \\
\hline D(LNINTR(-1)) & 0.069023 & 0.029633 & 2.329265 & $0.0290^{*}$ \\
\hline CointEq(-1) & -0.473520 & 0.114239 & -4.144991 & $0.0004^{*}$ \\
\hline $\begin{array}{l}\text { Cointeq }=\text { LNRGDP - }(0.1809 * \text { LNM2 +0.4395*LNGEXP - } 0.4373 * \text { LNREER + } \\
0.4468 * L N C P I+0.1446 * L N T O-0.3859 * L N I N T R+6.3319)\end{array}$ & & \\
\hline \hline
\end{tabular}

S o u r c e : computed from Eviews 9.5.

N o t e : the sign of “*” and "**” represents the level of significance at $1 \%$ and $5 \%$ respectively.

The short-run coefficients estimates obtained from the ECM version of ARDL model are given in table 6 . The ECM coefficient shows how quickly/slowly variables return to equilibrium. The error correction term $\mathrm{ECT}_{\mathrm{t}-1}$, which measures the speed of adjustment to restore equilibrium in the dynamic model, appear with negative sign and is statistically significant at 1 percent level, indicating that long run equilibrium can be attained. Our results are consistent with Banerjee, Dolado, Galbraith and Hendry (1998) who argue that a highly significant error correction term is further a proof of the existence of stable long 
run relationship. The coefficient of $\mathrm{ECT}_{\mathrm{t}-1}$ is equal to -0.474 , which implies that the deviation from the long-term equilibrium is corrected by 47.4 percent over each quarter of the year at 1 percent level of significance. The lag length of short run model is selected on the basis of Akaike information Criteria (AIC). In short run dynamics, our results reveal that economic growth in the short-run analysis is positively affected by the government expenditure and trade openness while price level negatively affects economic growth. Therefore, fiscal policy has powerful impact on economic growth than monetary policy in short run. Overall justification, the outcome confirms the theory that for a small open economy including Ethiopia having underdeveloped financial sector, fiscal policy is a more vital policy tool than monetary policy in accelerating economic growth, particularly in the short run. In the long-run, it is obvious that clear-cut and precise innovations in monetary policies as fiscal policies have equal significant effect on the economic growth over all the time horizons in Ethiopia. This result is also consistent with the result of Ozer and Kargol (2018) in Trukey and the study of Jayaraman, Cheeng and August (2012) in Vanuatu.

\section{Granger Causality}

According (Wooldridge, 2012) although cointegration indicates the presence of granger causality at least in one direction, it does not indicate the direction of causality between the variables. Among the different approach the direction of causality can be captured through error correction model which derived from long run co integrating vectors.

Accordingly, the Granger Causality test was conducted under the error correction model. First, the variables were estimated at level without taking first difference in the unrestricted VAR framework. The lag length was selected using the Akaike information criterion (AIC) was used to select the lag length. The unrestricted VAR model was employed with two lag so as to avoid serial correlation. to investigate the direction of causality between the variable, we used two granger causality types basically: (1) Short-run causality which can be captured by applying the Wald test for all the lag independent variables using the joint F-test; (2) long-run causality-obtained by confirming the coefficient of the error correction term having negative sign), which implies convergence of the system back to the long-run equilibrium position. 
Table 7. Short-run and Long-run Granger-Causality tests

\begin{tabular}{|c|c|c|c|c|c|c|c|c|}
\hline \multirow{2}{*}{$\begin{array}{l}\text { Dependent } \\
\text { variable }\end{array}$} & \multicolumn{7}{|c|}{ F-statistics (Short-run) } & \multirow{2}{*}{$\begin{array}{l}\text { t-statistics } \\
\text { (Long-run) }\end{array}$} \\
\hline & $\triangle$ LNRGDP & $\Delta$ LNM2 & $\Delta$ LNGEP & $\Delta$ LNREER & $\Delta$ LNINR & $\triangle \mathrm{LNCPI}$ & $\triangle$ LNTO & \\
\hline$\triangle \mathrm{LNRGDP}$ & - & 1.7811 & $3.364 * * *$ & $6.1051^{* * *}$ & $5.225^{* * *}$ & $4.673^{* *}$ & $5.381^{* *}$ & $-2.5423(-0.1968)$ \\
\hline$\triangle \mathrm{LNM} 2$ & $3.864^{*}$ & - & 1.348 & 1.909 & $3.981^{*}$ & 0.313 & 0.832 & $-2.2011(-0.0515)$ \\
\hline$\triangle$ LNGEP & $4.119 * *$ & 2.198 & - & 0.195 & 0.506 & $4.782 * *$ & 1.504 & $-1.325(-0.1545)$ \\
\hline$\triangle$ LNREER & $4.0475^{* *}$ & $7.817 * * *$ & $5.818^{* *}$ & - & $3.645^{*}$ & $10.454^{* * *}$ & 1.270 & $-1.541(-0.1835)$ \\
\hline$\Delta \mathrm{LNINR}$ & 1.3257 & $5.395^{* *}$ & 1.039 & $5.703^{* *}$ & - & $4.194 * *$ & $4.194^{* *}$ & $0.1774(0 . .283)$ \\
\hline$\triangle \mathrm{LNCPI}$ & $16.730 * * *$ & 15.858 & 10.243 & 8.085 & 5.636 & - & 2.214 & $3.9175(0.1835)$ \\
\hline$\Delta$ LNTO & 1.581 & 1.2398 & $3.599 *$ & 1.038 & 0.225 & $5.417 * *$ & - & $-0.4314(0.0498)$ \\
\hline
\end{tabular}

N o te: the sign of “*”,"**” and “***” represents the level of significance at $10 \%, 5 \%$ and $1 \%$ respectively.

S o u r c e : computed from Eviews 9.5.

All other control variables can also have causal effects, but for the purposes of this study, we are interested to examine the direction of causality between monetary policy, fiscal policy variables and economic growth in Ethiopia. Based on the findings in table 7, monetary measure rates do not "Granger-cause" economic growth in the form of short run causality, but economic growth "Granger-cause" the money supply. Moreover, there is bi-directional causality between fiscal policy measure, real effective exchange rate, real interest rate, and economic growth. However, based on long-run causality, the coefficients of the lagged error correction terms are negative and significant, and this confirms that a long-run relationship exists between the variables which offer evidence for uni-directional causality between the variables.

\section{CONCLUSION AND POLICY RECOMMENDATION}

This paper has investigated the comparative effectiveness of monetary and fiscal policies in affecting economic growth with particular reference to the case Ethiopia both in long run and short run, a subject which has been left for a debate in both developed and developing countries, including Ethiopia. The study examined with the help of ARDL Bounds testing approach to co-integration which has varieties advantage over other any method for small sample size. 
The argument of relative effectiveness has been got due attention over the world after global financial crisis in 2008. Accordingly, our results imply that there is a stable long run relationship among fiscal policy, monetary policy, control variables and economic growth, on which our analysis is based.

Based on our finding we additional inferred that in the short run the fiscal policy is relatively effective and that the monetary policy proxy by money supply is ineffective in affecting output growth in Ethiopia where as in long-run both monetary and fiscal policies variables are equal effective in accelerating economic growth in Ethiopia. The policy implications obtained from the analysis clearly suggest that monetary and fiscal policy plays a crucial role in influencing the level of economic activity in Ethiopia. Our result suggests the significance of incorporating both the monetary and fiscal policies in a single model when achieving macroeconomic objectives, thus both policies should be considered in tandem and not in isolation. However, the elasticity of output with respect to government expenditure is greater than elasticity of output with respect to money supply which is an indication of superior effectiveness of fiscal policy over monetary policies in Ethiopia in both long run and short run dynamics. Therefore, to have continuous and sustainable economic growth, the coordination of monetary and fiscal policies are vital and the lack of this coordination leads to a sharp downturn of overall economic performance, even can hurt the economy.

Thus, to promote maintain and strong economic growth, the National Bank of Ethiopia should give due attention on using appropriate monetary policy measures required to bring down the inflation to targeted rate and favorable interest rate where as government should apply effective fiscal policy to accelerate economic development through boosting aggregate demand as well. This inference does not mean separate implementation of policies by different institution rather policy makers in Ethiopia should be familiar with the fact that the accommodative monetary and fiscal policies simultaneously necessary not only for macroeconomic stabilization, but also to foster/boost overall economic growth in Ethiopia.

\section{UII REFERENCES}

Ali, S., Irum, S., \& Ali, A. (2008). Whether Fiscal Stance or Monetary Policy is Effective for Economic Growth in Case of South Asian Countries. The Pakistan Development Review, 47(4), 791-799. 
Andersen, L.C., \& Jordan, J.L. (1968). Monetary and fiscal actions: a test of their relative importance in economic stabilization. Federal Reserve Bank of St. Lotus Review, 11-23.

Asfaw, H.A. (2014). Trade policy and economic growth in Sub-Saharan Africa: A panel data approach. American Journal of Trade and Policy, 94-101.

Banerjee, A., Dolado, J., Galbraith, J., \& Hendry, D. (1998). ECM for Contegration in a Single Equation Framework. Statistics and econometrics series.

Baylie, F. (2011). The impact of real exchange rate in economic growth in Ethiopia. Adiss Abeba: Adiss Abeba University, unpubilished thesis.

Bokreta, K., \& Benanaya, D. (2016). The fiscal-monetary policy and economic growth in Algeria: VECM approach. International Journal of Social, Behavioral, Educational, Economic, Business and Industrial Engineering, 10(9). http://dx.doi.org/10.5281/zenodo.1126221.

Brown, R.L., Durbin, J., \& Evans, J.M. (1975). Techniques for testing the constancy of regression relationships over time. Journal of the Royal Statistical Society, B, 37, 149-163.

Brueckner, M., \& Lederman, D. (2015). Trade openness and economic growth: Panel data evidence from Sub-Saharan Africa. Economica, 82, 1302-1323.

Evans, O., \& Kelikume, I. (2018).The effects of foreign direct investment, trade, aid, remittances and tourism on welfare under terrorism and militancy. International Journal of Management, Economics and Social Sciences, 7(3),206-232. http://dx.doi. org/10.32327/IJMESS.7.3.2018.14.

Guerguil, M., Mandon, P., \& Tapsoba, R. (2017). Flexible fiscal rules and countercyclical fiscal policy. Journal of Macroeconomics, 52. http://dx.doi.10.106/j.jmacro.2017.04.007.

Havi, E.D.K., \& Enu, P. (2014). The Effect of Fiscal Policy and Monetary Policy on Ghana's Economic Growth: Which Policy Is More Potent? International Journal of Empirical Finance, 7(3), 61-75.

Jawaid, S.T., Arif, I., \& Naeemullah, S.M. (2010). Comparative Analysis of Monetary and Fiscal Policy: A Case Study of Pakistan. NICE Research Journal, 3, 58-67.

Jayaraman, T.K., Cheeng, C.K., \& August, L. (2012). A Study on Relative Effectiveness of Monetary and Fiscal policies in Vanuatu. Working series No. 2012/06.

Keho, Y. (2017). The impact of trade openness on economic growth: The case of Cote d'lvoire. Cogent Economics \& Finance, 5(1), 1-14. http://dx.doi.org/10.1080/23322 039.2017.1332820.

Lawal, A.I., Nwanji, T.I., Asaleye, A., \& Ahmed, V. (2016). Economic growth, financial development and trade openness in Nigeria: An application of the ARDL bound testing approach. Cogent Economics and Finance, 4, 1-15.

Meltzer, A.H. (1983). On Keynes and monetarism. London: Carnegie Mellon University Research Showcas.

Minyahil, A., Wndaferahu, M., \& Yilkal, W. (2016). Monetary Policy and Inflation Dynamics in Ethiopia: An Empirical Analysis. Global Journal of Human-Social Science: (E) Economics, 16(4), 45-60. 
MOFEC (2018). Fiscal policy in Ethiopia and recent developments. Addis Ababa.

Mohammad, S.D., Wasti, S.K.A., Lal, I., \& Hussain, A. (2009). An Empirical investigation between Money Supply, Government Expenditure, output \& Prices: the Pakistan Evidence. European Journal of Economics, Finance and Administrative Sciences, 7, 60-68.

NBE (2018). FDRE National Bank of Ethiopia. 2017/18, Addis Ababa.

Ogundari, K., \& Awokuse, T. (2018). Human capital contribution to economic growth in Sub-Sharan AfricaDoes health status matter more than Education? Economic Analysis and Policy, 58, 131-140.

Okorie, D., Sylvester, M.A., \& Simon-Peter, D-A.C. (2017). Relative Effectiveness of Fiscal and Monetary Policies in Nigeria. Asian Journal of Social Science Studies, 2(1), 117-129.

Owoye, O., \& Olugbenga, O.A. (1994). The Relative Importance of Monetary and Fiscal Policies in Selected African Countries. Applied Economics, 26, 1083-1091.

Polat, A., Shahbaz, M., Rehman, I.U., \& Satti, S.L. (2015). Revisiting linkages between financial development, trade openness and economic growth in South Africa: fresh evidence from combined cointegration test. Quality and Quantity, 49, 785-803. https://doi.org/10.1007/s11135-014-0023-x.

Özer, M., \& Karagöl, V. (2018). Relative effectiveness of monetary and fiscal policies on output growth in Turkey: an ARDL bounds test approach. Equilibrium. Quarterly Journal of Economics and Economic Policy, 13(3), 391-409. http://dx.doi.org/10.24136/ eq.2018.019.

Pesaran, H., \& Shin, Y. (1998). An autoregressive distributed lag modelling approach to cointegration analysis. In S. Strom (Ed.). Econometrics and Economic Theory in the 20th Century: The Ragnar Frisch Centennial Symposium. Cambridge: Cambridge University Press.

Pesaran, M. H., Shin, Y., \& Smith, R. J. (2001). Bounds testing approaches to the analysis of level relationships. Journal of Applied Econometrics, 16(3), 289-326.

Petrevski, G., Bogoev, J., \& Tevdovski, D. (2015). Fiscal and Monetary Policy Effects in Three South Eastern European Economies. Empirical Economics, 1-17.

Razzaque, M.A., Bidisha, S.H., \& Khondker, B.H. (2017). Exchange Rate and Economic Growth: An Empirical Assessment for Bangladesh. Journal of South Asian Development, 12(1), 42-64.

Şen, H., \& Kaya, A. (2015). The relative effectiveness of monetary and fiscal policies on growth: what does long-run SVAR model tell us? MPRA Paper, 65903.

Ulaşan, B. (2015). Trade openness and economic growth: panel evidence. Applied Economics Letters, 22(2), 163-167. http://doi.org/10.1080/13504851.2014.931914.

Vlastou, I. (2010). Forcing Africa to open up to trade: Is it worth it? The Journal of Developing Areas, 44(1), 25-39.

Wooldridge, J. (2012). Econometric Analysis of Cross-Section and Panel Data. Massachusetts: The MIT Press.

Zarra-Nezhad, M., Hosseinpour, F., \& Arman, S.A. (2014). Trade-Growth Nexus in Developing and Developed Countries: An Application of Extreme Bounds Analysis. Asian Economic and Financial Review, 4(7,) 915-929. 